\title{
Half-center oscillator computational models: the influence of neuronal parameters
}

\author{
Anca Doloc-Mihu*, Ronald L Calabrese \\ From Nineteenth Annual Computational Neuroscience Meeting: CNS*2010 \\ San Antonio, TX, USA. 24-30 July 2010
}

The rhythmic activity of the heartbeat neuronal network of the leech is based on pairs of inhibitory interneurons that make reciprocal spike-mediated and graded synapses across the ganglionic midline. Here we build upon our previous research, where we modeled such a pair of $\mathrm{HN}(4)$ reciprocally inhibitory interneurons, known as a half-center oscillator model [1]. We aim at investigating the changes in this model's oscillatory activity and bursting characteristics based on cellular and synaptic parameters.

To achieve this, we varied eight parameters in all combinations by using a brute-force approach, which resulted in a parameter space of 10,485,760 models. After changing a parameter, a model was run for $100 \mathrm{~s}$ to allow the system to establish stable activity, and then, it was run for another $100 \mathrm{~s}$, from which the data were recorded and analyzed.

We performed all the simulations and we built a SQL database table for their firing characteristics $[2,3]$. Now, we use the entire database to ask fundamental questions about the activity of half-center oscillators. First, we subdivide the models into those in which the component cells are intrinsically silent, spiking or bursting, and then, ask whether or not oscillators of these different types respond to parameter changes similarly.

The results we have so far show that in approximately $36.46 \%(3,823,240$ simulations $)$ of the models both cells were silent, in $27.72 \%(2,906,249)$ both cells were spiking, and in $22.03 \%(2,310,359)$ both cells were bursting. The rest of the simulations $(13.79 \%$ or $1,445,912)$ did not show symmetric activity in the two model cells. Out of the bursting models, in $18.96 \%(438,041)$ both cells showed irregular activity (Figure $1 \mathrm{~A}$ ), in $18.19 \%$ $(420,307)$ the component cells produced spikeless plateau potentials (Figure $1 \mathrm{~B}$ ), in $8.18 \%(189,041)$ the two cells showed asymmetric bursting activity, and in $54.67 \%$ $(1,262,970)$ both cells were bursting with standard bursting activity (Figure $1 \mathrm{C}$ ). We will now use this last sample of bursting models and then the entire database to ask mechanistic questions about their alternating

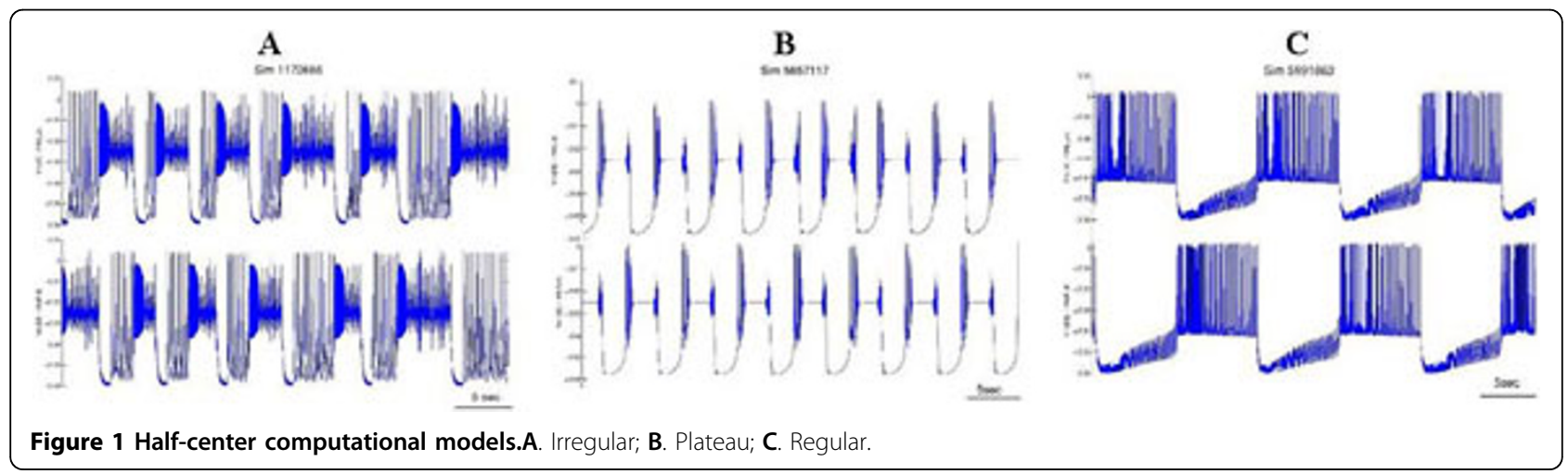

* Correspondence: adolocm@emory.edu
Department of Biology, Emory University, Atlanta, GA 30322, USA 
activity. We will be particularly interested in parameter changes which correspond to known neuromodulations such as the modulation of $\mathrm{h}$ current by myomodulin [4].

\section{Acknowledgements}

This work is supported by the National Institute Health Grant NS024072 to R. L.Calabrese.

Published: 20 July 2010

\section{References}

1. Hill AA, Lu J, Masino MA, Olsen OH, Calabrese RL: A model of a segmental oscillator in the leech heartbeat neuronal network. J Comput Neurosci 2001, 10:281-302.

2. Prinz A, Billimoria CP, Marder E: Alternative to hand-tuning conductancebased models: construction and analysis of databases of model neurons. J Neurophysiol 2003, 90:3998-4015.

3. Gunay C, Edgerton JR, Jaeger D: Channel densitydistributions explain spiking variability in the globus pallidus: a combined physiology and computer simulation database approach. J Neurosci. 2008, 28:7476-7491.

4. Tobin AE, Calabrese RL: Myomodulin increases Ih and inhibits the NA/K pump to modulate bursting in leech heart interneurons. J Neurophysiol 2005, 94(6):3938-3950.

doi:10.1186/1471-2202-11-S1-P57

Cite this article as: Doloc-Mihu and Calabrese: Half-center oscillator computational models: the influence of neuronal parameters. BMC Neuroscience 2010 11(Suppl 1):P57.

\section{Submit your next manuscript to BioMed Central} and take full advantage of:

- Convenient online submission

- Thorough peer review

- No space constraints or color figure charges

- Immediate publication on acceptance

- Inclusion in PubMed, CAS, Scopus and Google Scholar

- Research which is freely available for redistribution

Submit your manuscript at www.biomedcentral.com/submit 